\title{
PENINGKATAN HASIL BELAJAR PAI SISWA KELAS X SMA NEGERI 13 MAKASSAR MELALUI PENGGUNAAN KARTU KONSEP PADA KONSEP KHALIFAH (SURAH AL BAQARAH AYAT 30)
}

\section{Oleh: Mujizatullah. ${ }^{*>}$}

\begin{abstract}
The research aims to describe the improvement of student understanding on learning concept by using concept cards. Result shows that the use of concept card in religion course improves the student understanding. The writer, therefore, recommend to the teacher to use concept card techniques in Islam course
\end{abstract}

Keyword: concept card, learning, Islam

\section{PENDAHULUAN}

$\mathrm{P}$ ada hakekatnya pendidikan adalah suatu usaha untuk membudayakan manusia atau memanusiakan manusia. Manusia sendiri merupakan pribadi yang utuh dan kompleks sehingga sulit untuk dipelajari secara tuntas. Oleh karena itu, masalah pendidikan tidak pernah selesai sebab hakekatnya manusia sendiri selalu berkembang mengikuti dinamika hidupnya. Dalam keadaan seperti itu, pendidikan tetap memerlukan inovasi dalam metode pembelajaran yang sesuai dengan kemajuan ilmu pengetahuan dan teknologi tanpa mengabaikan nilainilai manusia, baik sebagai makhluk sosial maupun makhluk religius.

Pendidikan selalu berkenaan dengan upaya pembinaan manusia, maka keberhasilan pendidikan sangat bergantung pada unsur manusianya. Unsur manusia yang paling menentukan berhasil tidaknya pendidikan adalah guru. Guru merupakan ujung tombak pendidikan sebab guru secara langsung mempengaruhi, membina, mengenbangkan kemampuan siswa agar menjadi manusia yang cerdas,

*) Penulis adalah Peneliti Balai Penelitian dan Pengembangan Agama Makassar. 


\section{Mujizatullah}

terampil dan bermoral tinggi. Oleh karena itu, guru dituntut untuk memiliki kemampuan dasar yang diperlukan sebagai guru sekaligus pengajar. Salah satu cara yang dulakukan oleh guru adalah penetapan strategi mengajar yang tepat sehingga dapat meningkatkan keberhasilan belajar sisiwa. Keberhasilan tersebut ditandai dengan meningkatnya pengertian dan pemahaman siswa terhadap materi pembelajaran yang disampaikan oleh guru, kegiatan belajar siswa yang tidak tepat akan menyebabkan siswa sering bermain-main, berbicara atau melakukan aktivitas lain dalam proses belajar mengajar yang sebenarnya tidak sesuai dengan tujuan pendidikan. Sehingga untuk tercapainya proses belajar mengajar yang efektif harus digunakan metode yang multi arah dimana siswa terlebih langsung dan mengalami sendiri.

Namun kenyataan empirik menunjukkan guru pendidikan Agama Islam belum dapat menjalankan peran dan fungsinya secara optimal, melihat kenyataan ini komitmen serius dari pada guru PAI untuk terus menerus memperbaiki pembelajaran dalam rangka mencapai tujuan PAI yang bermutu merupakan suatu keniscayaan. Salah satu alternatif yang dapat dilakukan guru PAI untuk meningkatkan mutu pembelajaran adalah dengan mengimplementasikan dan meningkatkan inovasi dalam metode pembelajaran.

Salah satu masalah yang sering dijumpai dalam proses belajar mengajar di sekolah adalah kurangnya waktu dalam pencapaian tujuan pembelajaran sehingga belum memberikan ketuntasan sebagaimana yang diharapkan. Padahal efektivitas dalam pencapaian tujuan pembelajaran merupakan hal yang sangat diharapkan dalam proses belajar mengajar. Oleh sebab itu, penggunaan dan penerapan model pembelajaran yang efektif dan efisien sangat menentukan berhasil tidaknya pencapaian tujuan pembelajaran yang diinginkan. Untuk menetapkan suatu model pembelajaran yang efektif dan efisien diperlukan patokan yang bersumber dari beberapa faktor antara lain: materi pembelajaran yang diajarkan, tujuan pembelajaran yang ingin dicapai, siswa-siswa yang akan belajar, serta situasi dan kondisi kelas.

Pengajaran tradisional menitikberatkan pada metode imposisi, yakni pengajaran dengan cara menggunakan hal-hal yang dianggap penting oleh guru bagi murid. Cara ini tidak mempertimbangkan apakah bahan pelajaran yang diberikan itu sesuai atau tidak dengan kesanggupan, kebutuhan, minat dan tingkat kesanggupan/perkembangan, serta pemahaman murid. Tidak pula diperhatikan apakah bahan-bahan yang diberikan itu didasarkan pada motif-motif dan tujuan yang ada pada murid. 
Penyampaian fakta dan konsep setiap proses belajar mengajar melalui metode ceramah yang selalu diterapkan selama ini akan menjadikan siswa menjadi pengedar pasif di dalam kelas. Sebaliknya, guru sebagai sumber informasi utama. Oleh karena itu, aktifitas pembelajaran hanya ditekankan pada guru, maka guru harus pandai memilih kata-kata dan dengan suara yang cukup jelas dapat dimengerti dan menarik perhatian kelas. Hal tersebut menyebabkan dalam mengikuti proses belajar mengajar dengan menggunakan model pembelajaran seperti metode ceramah menyebabkan siswa kurang berminat dan bahkan bisa kehilangan motivasi belajar. Dengan demikian, tingkat pemahaman siswa terhadap materi pelajaran atau hasil yang diperoleh siswa bisa berakibat sangat rendah.

Kenyataan di lapangan, selama ini dalam proses belajar mengajar yang tidak atau yang kurang memberikan kesempatan kepada siswa untuk secara aktif memecahkan masalah sendiri akan memberikan hasil yang kurang memuaskan. Oleh karena itu, guru dituntut untuk menggunakan model pembelajaran yang dapat melatih siswa berhadapan dengan memecahkan beberapa masalah. Selain itu, siswa juga perlu diberikan kesempatan untuk mencari dan menemukan sendiri pemecahan masalah yang dihadapi tersebut sehingga dapat menghayati dan memahami materi pembelajaran yang diberikan.

Masa depan bangsa ditentukan oleh kualitas sumber daya manusianya maka peranan sistem pendidikan nasional termasuk metode pembelajaran dalam kehidupan bangsa menjadi sangat dominan. Oleh karena itu, pendidikan nasional harus selalu ditata agar benar-benar dapat menjadi wahan bagi pembangunan sumber daya manusia yang berkualtas. Hal ini sudah ditempuh oleh pemerintah yaitu menteri pendidikan dengan menggariskan kebijakan peningkatan mutu pendidikan.

Berdasarkan pada latar belakang di atas, fokus permasalahan dalam penelitian ini adalah:Bagaimana guru memotivasi siswa kelas X SMA Negeri 13 Makassar dalam proses belajar mengajar Pendidikan Agama Islam (PAI) melalui penggunaan kartu konsep pada konsep khalifah (surah Al Baqarah ayat 30$)$.

Penelitian ini adalah penelitian tindak kelas. Penelitian tindakan kelas ini dilaksanakan dengan 2 siklus dengan perincian sebagai berikut: 
Mujizatullah

- Penjelasan singkat tentang konsep ditulis oleh siswa pada halaman belakang kartu konsep.

\section{c) Observasi dan evaluasi}

- Keaktifan siswa mengidentifikasi konsep.

- Kemampuan siswa memberikan penjelasan tentang konsep yang ditulisnya pada kartu konsep.

- Kemampuan siswa memberikan tanggapan terhadap konsep yang dipaparkan temannya.

- Hasil tindakan dievaluasikan dengan memberikan tes yang berfungsi sebagai ulangan harian.

\section{d) Refleksi}

Hasil observasi dan evaluasi dianalisis untuk dijadikan bahan pikiran dalam merefleksi kegiatan selama kegiatan dilakukan. Pada tahap ini dilihat sampai dimana hasil relajar yang diperoleh siswa estela proses belajar mengajar. Hal-hal yang masi dipandang kurang: menjelaskan, beratnya, dan memberi tanggapan serta cara pengisian pada kartu konsep dilakukan perbaikan pada siklus II sehingga keaktifan dan pencapaian hasil belajar Pendidikan Agama Islam (PAI) lebih meningkat.

\section{2) Siklus II}

Siklus ini dilakukan sebanyak empat jam pelajaran (dua kali pertemuan). Pada siklus ini dilakukan langkah-langkah yang relatif sama pada siklus pertama dengan beberapa perbaikan misalnya dengan memperdalam penerapan pendekatan konsep dan pendekatan deduktif. Yaitu mengaplikasi konsep kompleks ke unit yang sederhana berdasarkan hasil refleksi siklus I.

\section{KERANGKA KONSEPTUAL}

\section{Pengertian Belajar}

Faktor-faktor yang mempengaruhi belajar banyak jenisnya, tetapi dapat digolongkan menjadi 2 golongan saja, yaitu faktor intern dan faktor ekstern. Faktor intern, belajar adalah faktor yang be^asal dari dalam individu yang sedang belajar, sedangkan faktor ekstern, belajar adalah yang ada di luar individu di antaranya metode mengajar.

Pada hakekatnya belajar adalah suatu proses yang di tandai dengan adanya perubahan dalam diri seseorang, perubahan sehingga hasil dari proses belajar 
dapat ditunjukkan dalam berbagai bentuk seperti perubahan pengetahuan, siswa dan tingkah laku, keterampilan, kecakapan, kebiasaan, serta perubahan aspek lain yang ada pada seseorang yang belajar.

Banyak ahli yang memberi batasan atau defmisi tentang belajar, diantaranya menurut Slameto mengemukakan tentang pengertian belajar bahwa " belajar adalah suatu proses usaha yang dilakukan individu untuk memperoleh suatu perubahan tingkah laku yang baru secara keseluruhan sebagai hasil pengalaman individu itu sendiri dalam interaksi dalam lingkungannya".2

Belajar adalah suatu proses yang kompleks yang terjadi pada semua orang dan berlangsung sumber hidup. Menurut Abdurrahman, belajar adalah suatu perubahan pada diri individu sebagai akibat atau hasil interaksi antar indivisu dengan lingkungannya yang menjadikannya mendapatkan kemampuan yang lebih tinggi untuk hidup secara wajar dalam lingkungannya. ${ }^{3}$

Menurut Nasution, ciri-ciri kegiatan yang disebut belajar adalah sebagai berikut ${ }^{4}$ :

1) Belajar adalah aktivitas yang menghasilkan perubahan pada diri individu yang belajar baik yang aktual maupun potensial.

2) Perubahan itu pada dasarnya berupa didapatkannya kemampuan baru yang berlaku dalam waktu yang relatif lama.

3) Perubahan itu terjadi karena usaha.

Belajar membawa suatu perubahan pada diri individu yang belajar, perubahan itu tidak hanya mengenai jumlah pengetahuan, tetapi juga bentuk kecakapan-kecakapan, kebiasaan, sikap, pengertian, minat dan penyesuaian diri. ${ }^{5}$

Menurut Hamalik tujuan belajar adalah sejumlah hasil yag menunjukkan bahwa siswa telah melakukan perbuatan belajar, yang umumnya meliputi pengetahuan, ketermpilan dan sikap-sikap yang baru, yang diharapkan dapat tercapai oleh siswa. ${ }^{6}$

Pendapat para ahli tersebut berbeda-beda tentang pengertian belajar, namun pada hakekatnya memiliki kesamaan dalam hal terjadinya perubahan tingkah laku dalam diri seseorang yang belajar. Oleh karena itu, belajar pada dasarnya adalah suatu proses usaha yang dilakukan seseorang untuk memperoleh perubahan tingkah laku yang baru keseluruhan sebagai hasil pengalamannya sendiri dalam interaksi dengan lingkungannya. 


\section{Pengertian Mengajar}

Tugas seorang guru dalam mengajar tidak terlepas dari tujuan belajar. Mengajar adalah membelajarkan si pelajar atau peserta didik dalam rangka mencapai tujuan pendidikan. Menurut Gledler mengajar diartikan dengan suatu keadaan untuk menciptakan situasi yang mampu merangsang siswa untuk belajar.' Situasi ini tidak harus berupa transformasi pengetahuan dari guru kepada siswa saja, tetapi dapat dengan cara lain misalnya belajar melalui media pembelajaran yang sudah disiapkan. Sementara itu dalam keseharian di sekolahsekolah, istilah pembelajaran atau proses pembelajaran sering dipahami sama dengan proses belajar mengajar dimana didalamnya ada interaksi antara guru dan siswa dan antara sesama siswa untuk mencapai tujuan yaitu terjadinya perubahan sikap dan tingkah laku siswa.

Mengajar pada umumnya usaha guru untuk menciptakan kondisi-kondisi atau mengatur lingkungan sedemikian rupa, sehingga terjadi interaksi antara murid dengan lingkungannya, termasuk guru, alat pelajaran dan sebagainya yang disebut proses belajar, sehingga tercapai tujuan belajar yang telah ditentukan. ${ }^{8}$

Menurut Roestiyah yang dimaksud dengan metode mengajar adalah suatu pengetahuan tentang cara mengajar yang dilakukan oleh guru. Selain itu, metode mengajar dapat pula diartikan sebagai instruktur atau strategi yang dikuasai guru untuk mengajar dan menyajikan bahan pelajaran kepada siswa dalam kelas agar pelajaran pelajaran tersebut dapat ditangkap, dipahami, dan digunakan oleh siswa dengan baik, dalam memilih metode mengajar yang akan digunakan dalam proses pembelajaran Pendidikan Agama Islam (PAI).

Metode belajar yang diterapkan dalam proses pembelajaran PAI yang efektif bila menghasilkan yang sesuai dengan apa yang diharapkan. Semakin besar pengaruhnya untuk menghasilkan sesuatu diharapkan itu relatif menggunakan tenaga, usaha, pengolahan biaya, dan waktu minimum atau semakin kecil tenaga, usaha, biaya dan waktu yang dikeluarkan, maka semakin efisien metode tersebut.

Itulah pengertian yang dikemukakan oleh para ahh, maka dapat disimpulkan bahwa mengajar adalah suatu akti vitas untuk membimbing seseorang mendapatkan pengetahuan atau mengubah tingkah laku serta mengembangkan cita-cita.

\section{Proses Belajar Mengajar}

Mengajar dan belajar adalah suatu proses yang'tidak dapat dipisahkan, suatu pengajaran akan berhasil apabila terjadi proses mengajar dan proses belajar yang harmonis. 
Proses belajar mengajar dengan suatu pendidikan khususnya di sekolahsekolah merupakan kegiatan inti dalam mencapai suatu tujuan pendidikan. Menurut Sahabuddin proses belajar mengajar adalah suatu peristiwa yang melibatkan dua pihak guru dan siswa dengan tujuan yang sama, yaitu dengan meningkatkan prestasi belajar, tetapi dengan pemikiran yang berbeda. ${ }^{10}$

Menurut Sudjana, asumsi yang melandasi hakikat belajar mengajar" yaitu:

a) Peristiwa belajar terjadi apabila subjek didik secara aktif berinteraksi dengan lingkungan belajar yang diatur oleh guru

b) Proses belajar mengajar yang efektif memerlukan strategi dan metode/ teknologi pendidikan yang tepat

c) Program belajar mengajar dirancang dan dilaksanakan sebagai suatu sistem

d) Proses dan produk belajar perlu memperoleh perhatian yang seimbang

e) Pembentukan kompetensi profesional memerlukan pengintegrasian fungsional antara teori dan praktek serta materi dan metodelogi penyampaiannya

f) Pembeentukan kompeten si profesional memerlukan pemgalaman lapangan yang bertahap mulai dari pengalaman medan, latihan keterampilan terbatas sampai dengan pelaksanaan dan penghayatan tugas-tugas kependidikan secara lengkap dan aktual

g) Kriteria keberhasilan yang utama dalam pendidikan profesional adalah pendemonstrasian penguasaan konsumen

h) Materi penyajian, sistem penyampaiannya selalu berkembang.

\section{Penggunaan Kartu Konsep dalam Pembelajaran}

Konsep adalah klasifikasi rangsangan yang berciri-ciri sama, rangsangan itu dapat berupa objek-objek kejadian atau pribadi. Selain itu konsep adalah suuatu gagasan yang diregenerasikan dari pengalaman-pengalaman tertentu dan relevan. ${ }^{2}$

Menurut Wilis konsep-konsep merupakan dasar berfikir untuk belajar aturan-aturan pada akhirnya untuk memecahkan masalah. Hal ini berarti konsep merupakan dasar bagi proses mental yang lebih tinggi untuk merumuskan prinsip-prinsip dan generalisasi maupu untuk memecahkan masalah.

Tipe belajar pembentukan konsep \{concept formation) yang disebut juga tipe pengelompokan adalah belajar melihat (mengenal) sifat bersama peristiwa kongkrit untuk dijadikan suatu kelompok. 
Prinsip-prinsip untuk mempelajari konsep, seperti halnya untuk mempelajari informasi fakta dinyatakan sebagai kondisi atau pekerjaan yang dapat dilaksanakan oleh siswa untuk memudahkannya dalam mempelajari konsepkonsep. Penguasaan informasi adalah penting untuk mempelajari konsep dan informasi untuk konsep dan penerapannya dapat diperoleh melalui membaca dan mempelajari bahan-bahan tertulis. ${ }^{14}$

Belajar dengan konsep bertujuan untuk mengaktifkan siswa dalam belajar dan memudahkannya dalam memahami materi pelajaran serta lebih mengefektifkan proses belajar mengajar sesuai dengan tujuan kurikulum yang ingin dicapai.

Tingkatan konsep menurut Arman ada lima ${ }^{15}$ yaitu:

- konsep konkret yang berasal dari pengalaman

- konsep abstrak yang merupakan arahan dari konsep generalisasi.

- konsep generalisasi yang berasal dari gambaran mental yang terbentuk dari pengalaman-pengalaman.

- konsep analisis, berhubungan dengan pemisahan atau pemecahan berbagai pengerian konsep.

- $\quad$ konsep sintetis, pnyusunan kembali konsep-konsep dasar.

- penggunaan kartu konsep dalam psoses belajar mengajar Pendidikan Agama Islam.

Kartu konsep dapat juga merupakan ringkasan dari hasil belajar. Sasaran utama strategi penggunaan kartu konsep dalam proses belajar mengajar adalah untuk meningkatkan penguasaan materi serta konsep-konsep dalam proses belajar mengajar adalah untuk meningkatkan penguasaan materi serta konsepkonsep mendasar dari bidang studi yang dipelajari. Penjelasan pendahuluan mengarahkan perhatian siswa pada materi yang tercakup dalam satuan pelajaran terbaru. Penjelasan itu pada umumnya menyajikan suatu judul yang mencakup keseluruhan bahan yang kemudian dijabarkan beberapa bagian kecil, masingmasing dengan topik sendiri yang ditulis pada kartu konsep.

\section{Hasil Belajar}

Hasil belajar merupakan kemampuan maksimum yang dicapai akibat dari perlakuan dalam kegiatan. Sehubungan dengan hal tersebut, maka batasan tentang hasil belajar seperti yang dikemukakan oleh Bahri bahwa hasil belajar adalah taraf kemampuan aktual yang bersifat terukur, berupa penguasaan ilmu 
Mujizatullah

pengetahuan, keterangan, sikap interprestasi yang dicapai oleh siswa dan apa yang dihadapi siswa di sekolah. ${ }^{16}$

Menurut Mappa, hasil belajar adalah nilai yang dicapai siswa dalam bidang studi tertentu dengan menggunakan standar sebagai pengukuran keberhasilan belajar seseorang. ${ }^{17}$ Selanjutnya, menurut Abdullah bahwa hasil belajar merupakan indikator kualitas dan pengetahuan yang oleh siswa. Hasil belajar dapat menjadi indikator untuk mengukur sedikit banyaknya pengetahuan yang dikuasai oleh bidang studi atau kegiatan kurikulum tertentu.

Hasil belajar tidak akan yang dihasilkan selama seseorang tidak akan melakukan kegiatan. Pada kenyataannya hasil belajar tidak semuda apa yang dibayangkan, tetapi penuh perjuangan dengan berbagai tantangan yang harus dihadapi untuk mencapainya. Oleh karena itu, sangatlah kompleks dengan bermacam-macam kegiatan seperti mendengar, mengingat, membaca, berdemonstrasi, berbuat sesuatu serta menggunakan pengalaman maka dapatl dikatakan bahwa proses yang menghasilkan suatu perubahan pada individu yang belajar dan dimanifestasikan dengan tingkah laku adalah hasil belajar.

\section{, Tinjauan Umutn tentang Konsep Khalifah (Surah Al Baqarah Ayat 30)}

Manusia diciptakan Allah swt, di dunia mempunyai dua fungsi yaitu sebagai hamba Allah dan sebagai khalifah Allah di bumi. Khalifah merupakan orang yang diberi kepercayaan untuk mengelola dan merawaambu-rambu Allah bumi serta mengatur kehidupan di muka bumi ini dengan mengacu kepada Allah swt. Dan bermamfaat bagi ummat bagi ummat manusia.

Surah Al Baqarah Ayat 30: "Ingatlah ketika Tuhanmu herfirnian kepada para malaikat, sesungguhnya Aku hendak menjadikan (khalifah) di bumi itu orang yang akan membuat kerusakan padanya dan menumpahkan darah.padahal kami senantiasa bertasbih dengan memuji engkau dan menyucikan Engkau, Allah berfirtnan, Sesungguhnya Aku mengetahui apa yang tidak kamu ketahui". (QS AL Baqarah : 30)

Manusia yang ditugaskan sebagai khalifah di bumi harus mampu membaca dan memahami isi kandungan Alquran dan mampu membaca alam. Manusia sebagai khalifah Allah harus mampu menguasai ilmu pengetahuan sebagai bekal untuk hidup di dunia dan di akhirat kelak. Ketika manusia mengelola dan merawat bumi serta mengatur kehidupan agar sejahtera dan damai, manusia senantiasa menghadapi rintangan dan godaan dari iblis atau setan agar tersesat ke jalan yang tidak diridhai oleh Allah SWT. 


\section{TEMUAN DAN PEMBAHASAN}

1. Hasil belajar PAI siswa kelas X SMA Negeri 13 Makassar setelah pelaksanaan tindakan siklus I melalui penggunaan Kartu Konsep pada konsep khalifah dapat dilihat pada tabel 1 di bawah ini:

Tabel 1: Rangkuman nilai statistik hasil belajar PAI setelah pelaksanaan siklus 1 melalui penggunaan Kartu Konsep.

\begin{tabular}{|c|c|}
\hline Uraian & Nilai \\
\hline Nilai Tertinggi & $\mathbf{7 , 8 0}$ \\
Nilai terendah & $\mathbf{5 , 5 0}$ \\
Nilai Rata-rata & $\mathbf{6 , 6 0}$ \\
Standar Deviasi & $\mathbf{0 , 5 9}$ \\
\hline
\end{tabular}

Data pada tabel 1 menunjukkan bahwa nilai tertinggi yang diperoleh adalah 7,80, nilai rata-rata 6,60 dan keseluruhan nilai yang diperoleh siswa, jika dikelompokkan dalam 5 kategori maka distribusi, frekwensi,presentase dan kategori hasil belajar PAI siswa setelah pelaksanaan siklus 1 dapat dilihat pada tabel 2.

Tabel 2: Destribusi frekwensi, Persentase dan Kategori Hasil Belajar Siswa setelah

\begin{tabular}{|c|c|c|c|}
\hline $\begin{array}{c}\text { Tingkat } \\
\text { Penguasaan }\end{array}$ & Kategori & Frekuensi & Presentase \\
\hline 9,0-10 & Tinggi Sekali & 0 & 0 \\
$7,5-8,9$ & Tinggi & 9 & 22,5 \\
$5,5-7,4$ & Sedang & 31 & 77,5 \\
$4,0-5,4$ & Kurang & 0 & 0 \\
$0-3,9$ & Kurang sekali & 0 & 0 \\
\hline \multicolumn{2}{c}{ Jumlah } \\
\hline
\end{tabular}

Data pada tabel 2 menunjukkan bahwa dari 40 siswa yang menjadi objek penelitian, setelah pelaksanaan siklus 1 memperoleh hasil belajar yaitu, 22,5 \% memperoleh hasil belajar yang dikategorikan tinggi sekali, 77,5 dikategorikan tinggi, $0 \%$ dilkategorikan sedang, $0 \%$ dikategorikan kurang dan kurang sekali. 
Tabel 5: Distribusi, Presentase keaktifan siswa selama pembelajaran dengan menggunakan kartu konsep

\begin{tabular}{|c|l|c|c|c|c|c|c|}
\hline \multirow{2}{*}{ No } & \multirow{2}{*}{ Keaktifan } & \multicolumn{3}{|c|}{ Siklus I } & \multicolumn{3}{c|}{ Siklus II } \\
\cline { 3 - 8 } & & \multicolumn{3}{|c|}{ Pertemuan } & \multicolumn{3}{c|}{ Pertemuan } \\
\cline { 3 - 8 } & & I & II & Irerata & I & II & Rerata \\
\hline 1 & Mengidentifikasi Konsep & $\mathbf{9 1 , 9 2}$ & 100 & $\mathbf{9 5 , 7 1}$ & $\mathbf{4 , 2 8}$ & 100 & $\mathbf{9 7 , 1 4}$ \\
\hline 2 & Menjelaskan Konsep & 14,28 & 20 & 17,14 & 17,14 & 22,85 & 19,99 \\
\hline 3 & Bertanya Setelah Penjelasan & 14,28 & 14,28 & 14,28 & 14,28 & 20 & 17,14 \\
\hline 4 & Kerja Sama di Kelompoknva & $\mathbf{9 1 , 4 2}$ & 100 & 20 & $\mathbf{8 , 5 7}$ & $\mathbf{2 0}$ & 14,28 \\
\hline
\end{tabular}

Pada Tabel 5 menunjukkan ada peningkatan siswa ${ }^{19}$ selama proses pembelajaran hal ini terlihat dengan siswa yang mampu mengidentifikasi konsep yaitu dari $95,71 \%$ menjadi $97,14 \%$ kemampuan bertanya setelah penjelasan konsep yaitu dari 17,14 menjadi 19,99, kemampuan bertanya setelah penjelasan konsep dari $14,28 \%$ menjadi 19,99, kemampuan bertanya setelah penjelasan konsep dari 14,28\% menjadi 17,14, kemampuan siswa kerjasama dengan kelompoknya dari $95,71 \%$ menjadi $97,14 \%$, kemampuan siswa memberi tanggapan dari $20 \%$ menjadi 27,14 .

\section{Diskusi Penelitian}

Berdasarkan hasil analisis data yang telah diuraikan di atas, maka secara kuantitatif hasil penelitian tindakan kelas ini memperlihatkan adanya peningkatan hasil belajar PAI dan aktivitas keterlibatan dalam proses belajar mengajar siswa setelah pelaksanaan tindakan siklus Ike Pelaksanaan Siklus II.

Setelah proses belajar mengajar dengan kartu konsep diberikan pada setiap akhir siklus untuk mengetahui hasil belajar PAI yang diperoleh siswa. Dari dua Siklus pelaksanaan tindakan yang dilaksanakan, menunjukkan adanya kemajuan dan peningkatan nilai rata-rata hasil belajar PAI siswa. Hasil belajar siswa pada Siklus I dikategorikan sedang karena dapat $31(77,5),(22,5 \%)$ dengan nilai kategori tinggi, dan tidak ada kategori tinggi sekali.

Hasil penelitian Siklus II menunjukkan adanya kemajuan dan peningkatan hasil belajar PAI siswa dari pelaksanaan tindakan siklus I. hal ini terlihat dari nilai yang diperoleh siswa yakni dapat dikategorikan tinggi karena terdapat 6 (15\%) siswa yang memperoleh nilai kategori tinggi sekali, 25 (62,50\%) dengan kategori tinggi, $9(22,50 \%)$ siswa dengan kategori sedang serta tidak ada untuk kategori kurang dan kurang sekali.

Adanya peningkatan hasil belajar dari siklus I ke Siklus II disebabkan karena siswa sudah diberikan pemahaman cara menemukan konsep-konsep penting 
selama proses belajar mengajar, selain itu siswa menunjukkan kemampuannya kepada teman-temannya dengan cara aktif memberikan penjelasan terhadap konsep yang ditemukan,bahkan siswa memberikan tanggapan terhadap konsep yang dibuat oleh temanya.

Hasil belajar PAI siswa setelah proses belajar mengajar baik Siklus I maupun Siklus II merupakan keberhasilan dalam pembelajaran dengan menggunakan kartu konsep, Hal ini ditandai dengan adanya peningkatan nilai rata-rata pelajaran PAI yang diperoleh siswa. Aktivitas siswa dalam menemukan konsep merupakan pembelajaran yang berpusat pada siswa dengan indikasi bahwa guru bukan satu-satunya sebagai informasi. Oleh karena itu, kerja sama antara siswa dan guru dalam proses belajar mengajar sangat penting peranannya. Proses komunikasi dalam kegiatan belajar mengajar tidak hanya dua arah tapi banyak arah. Aplikasi penerapan penggunaan kartu konsep memungkinkan komunikasi multi arah (guru, siswa) sehingga dapat meningkatkan hasil belajar PAI siswa.

Hasil penelitian tentang keaktifan siswa dalam proses belajar mengajar dari Siklus I ke Siklus II mengalami peningkatan. Hal ini disebabkan karena pembelajaran dengan menggunakan kartu konsep, siswa menjadi aktif dalam proses belajar mengajar serta menemukan sendiri konsep dan mudah memahami apa yang ditulis dalam konsep tersebut.

Demikian pula hasil refleksi pada Siklus I keaktifan siswa yang meliputi memberikan tanggapan juga mengalami peningkatan pada Siklus II hal ini menunjukkan kognitif dan Psikomotorik siswa tersebut mengalami perkembangan.

\section{PENUTUP}

\section{Kesimpulan}

Berdasarkan hasil penelitian yang dilakukan dapat di simpulkan bahwa hasil belajar PAI siswa setelah proses belajar mengajar dengan menggunakan kartu konsep mengalami peningkatan dimana pada siklus I dikategorikan sedang dengan persentase sebesar $77,50 \%$ dan nilai tinggi sebesar $22,50 \%$ dan setelah pelaksanaan Siklus II dikategorikan tinggi dengan persentase sebesar 62,50\% (mengalami peningkatan) dan yang memperoleh nilai tinggi sekali $15 \%$ yang pada Siklus I tidak ada sedangkan nilai sedang mengalami penurunan dari 77,50\% menjadi $22.50 \%$. 


\section{Rekumendasi}

Berdasarkan kesimpulan yang telah dikemukakan di atas, maka penulis menyarankan:

1. Guru bidang studi PAI agar dalam proses pembelajaran dapat menerapkan penggunaan kartu konsep sehingga dapat meningkatkan pemahaman, hasil belajar dan keaktifan siswa.

2. Kepada siswa, disarankan agar lebih aktif menemukan konsep sendiri dalam proses belajar mengajar sehingga lebih memahami materi pelajaran dan dapat meningkatkan hasil belajar PAI.[*]

\section{Catatan Akhir:}

' Penulis adalah peneliti pada Balai Penelitian dan Pengembangan Agama Makassar.

${ }^{2}$ Slameto. 1995. Proses Mengajar dalam Sistem Kredit Semester. Jakarta: Bumi Aksara.,h. 2

'Abdurrahman. 1994 Pengelolaan Pengajaran. Ujung Pandang : Bintang Selatan.

' S. Nasution. 1998. Kurikulumdan Pengajaran. Bandung : Bumi Aksara.

${ }^{5}$ Sahabuddin. 2002. Mengajar dan Belajar. Makassar. Universitas Makassar.

' O. Hamalik. 1994. Kurikulum dan Pembelajaran. Bandung : Bumi Aksara.

' Lihat dalam Muhibbin Syah. 1995. Psikologi Pendidikan Suatu Pendekatan Baru. Bandung: Remaja Rosdakarya.

${ }^{8}$ Nasution. 1982. Teknologi Pendidikan. Bandung : Bumi Aksara.

’ NK. Roestiyah.1988. Didaktik Metodik.. Jakarta : Rineka Cipta.

${ }^{10}$ Sahabuddin. op.cit.,

" N. Sudjana. 1987. Dasar-dasar Proses belajar Mengajar. Bandung : SinarBaruAlgesindo.

${ }^{12}$ G Brown. 1990. Pengajaran Mikro Program Keterampilan Mengajara, Surabaya: Usaha Airlangga University Press.

${ }^{13}$ Lihat dalam O. Hamalik. 2001. Proses Belajar Mengajar. Bandung : Bumi Aksara.

"Slameto., op.cit.

${ }^{15}$ S. Arman. 2002. Strategi Belajar Mengajar. Makassar : Jurusan Biologi FMIPA UNM.

${ }^{16}$ D.S Bahri. 1984. Prestasi Belajar dan Kompetensi Guru, Surabaya: Usaha Nasional

"Mappa. 1970. Psikologi Pendidikan. Ujungpandang: Fak. Ilmu Pendidikan IKIP

${ }^{18}$ Abdullah. 1989. Pokok-Pokok Layanan Bimbingan Belajar. Ujungpandang: Fakultas Ilmu Pendidikan IKIP. 
Mujizatullah

\section{DAFTAR PUSTAKA}

Abdurrahman, 1994 Pengelolaan Pengajaran. Ujung Pandang : Bintang Selatan.

Abdullah, A. E. 1989. Pokok-pokok Layanan Bimbingan Belajar. Ujung Pandang : Fakultas Ilmu Pendidikan IKIP Ujung Pandang.

Arman, S. 2003. Strategi Belajar Mengajar. Makassar : Jurusan Biologi FMIPA UNM.

Bahri, D.S. 1984. Prestasi Belajar dan Kompotensi Guru. Surabaya : Usaha Nasional.

Brown, G. 1990. Pengajaran Mikro Program Keterampilan Mengajar. Surabaya : Usaha Airlangga University Press.

Hamalik, O. 1994. Kurikulum dan Pembelajaran. Bandung : Bumi Aksara.

Mappa, S.1970. Psikologi Pendidikan. Ujung Pandang : Fakultas Ilmu Pendidikan IKIP Ujung Pandang.

Muhibbin Syah. 1995. Psikologi Pendidikan Suatu Pendekatan Baru. Bandung : Remaja Rosdakarya.

Nasution, 1982. Teknologi Pendidikan. Bandung : Bumi Aksara.

Nasution, S. 1998. Kurikulum dan Pengajaran. Bandung : Bumi Aksara.

Roestiyah, N.K. 1998. Didaktik Metodik.. Jakarta : Rineka Cipta.

Sahabuddin. 2002. Mengajar dan Belajar. Makassar. Universitas Makassar.

Slameto. 1995. Proses Mengajar dalam Sistem Kredit Semester. Jakarta : Bumi Aksara.

Sudjana, N. 1987. Dasar-Dasar Proses Belajar Mengajar. Bandung : Sinar BaruAlgesindo. 
Mujizatullah

\section{DAFTAR PUSTAKA}

Abdurrahman, 1994 Pengelolaan Pengajaran. Ujung Pandang : Bintang Selatan.

Abdullah, A. E. 1989. Pokok-pokok Layanan Bimbingan Belajar. Ujung Pandang : Fakultas Ilmu Pendidikan IKIP Ujung Pandang.

Arman, S. 2003. Strategi Belajar Mengajar. Makassar : Jurusan Biologi FMIPA UNM.

Bahri, D.S. 1984. Prestasi Belajar dan Kompotensi Guru. Surabaya : Usaha Nasional.

Brown, G. 1990. Pengajaran Mikro Program Keterampilan Mengajar. Surabaya : Usaha Airlangga University Press.

Hamalik, O. 1994. Kurikulum dan Pembelajaran. Bandung : Bumi Aksara. , 2001. Proses Belajar Mengajar. Bandung : Bumi Aksara.

Mappa, S.1970. Psikologi Pendidikan. Ujung Pandang : Fakultas Ilmu Pendidikan IKIP Ujung Pandang.

Muhibbin Syah. 1995. Psikologi Pendidikan Suatu Pendekatan Baru. Bandung : Remaja Rosdakarya.

Nasution, 1982. Teknologi Pendidikan. Bandung : Bumi Aksara.

Nasution, S. 1998. Kurikulum dan Pengajaran. Bandung : Bumi Aksara.

Roestiyah, N.K. 1998. Didaktik Metodik. Jakarta : Rineka Cipta.

Sahabuddin. 2002. Mengajar dan Belajar. Makassar. Universitas Makassar.

Slameto. 1995. Proses Mengajar dalam Sistem Kredit Semester. Jakarta : Bumi Aksara.

Sudjana, N. 1987. Dasar-Dasar Proses Belajar Mengajar. Bandung : Sinar BaruAlgesindo. 